\title{
РЕЗУЛЬТАТИВНІСТЬ ПСИХОЛОГІЧНОГО СУПРОВОДУ ДЛЯ РОЗВИТКУ ПОКАЗНИКІВ ОСОБИСТІСНОГО ФУНКЦІОНУВАННЯ ЧЛЕНІВ СІМЕЙ, ЩО МАЮТЬ ПРОБЛЕМНИХ ДІТЕЙ
}

\section{Мушкевич Мирослава}

\author{
Волинський національний університет імені Лесі Українки, \\ Луцьк, Україна \\ miramush@yahoo.com \\ https://orcid.org/0000-0002-3268-5767
}

Мета. Процес психологічного супроводу сімей, що мають проблемних дітей, спрямований на вивчення особливостей особистісного функціонування дорослих членів сімейної системи, їхнього психологічного стану, кола проблем, завдань для їх розв'язання, зануренням у реальне життя сім'ї.

Методи. Етапність психологічного супроводу передбачає первинну діагностику та обговорення результатів стандартизованих i проєктивних методик; вивчення прогалин у знаннях членів сім'ї щодо особливостей особистісного функціонування на рівні шлюбної та батьківської підсистем і надання конкретно-необхідної інформації розвитку психологічної культури; консультування щодо покращення особистісної та міжособистісної взаємодії; опрацювання індивідуальних та сімейних дисфункцій психотерапевтичними методами за допомогою складання діаграми, написання казки, опису метафоричної сімейної скрині.

Результати. Змістовні ресурси психологічного супроводу орієнтовані на прогностичні та значущі особистісні предиктори розвитку особистісного функціонування дорослих членів сімейної системи: низький рівень вираження «гіпопротекції»; позитивне ставлення до дитини; низький рівень розширення сфери батьківських почуттів; кооперація 3 дитиною; обернено пропорційний шизоїдний тип акцентуації; низький рівень симбіозу з дитиною; низький рівень вираження «потурання»; обернено пропорційний рівень мінімальності санкцій; обернено пропорційний епілептоїдний тип.

Висновки. Запропоновані складові елементи психологічного супроводу сприяють подоланню негативної психологічної симптоматики та підвищенню функціональності сімейної системи. Виокремлено на психодіагностичному етапі симптоми й проблеми та розглянуто як результат неоптимальних, дисфункційних взаємодій членів сім'ї, а не як атрибут того чи іншого ії члена. Фокусами психоедукаційного, психоконсультативного та психотерапевтичного впливу стали виділені чотири неконструктивні особистісні та міжособистісні

ISSN 2308-3743 (Online), ISSN 2227-1376 (Print)

(C) Мушкевич М., 2021. Ця стаття відкритого доступу на умовах CC BY-NC 4.0 
чинники, як-от «інтровертовано-педантична особистісна диспозиція», «домінантно-агресивна особистісна диспозиції», «психастенічна особистісна диспозиція», «потуральної виховної диспозиції».

Ключові слова: психологічний супровід, особистісні характеристики, ядерна сім'я, проблемна дитина, психодіагностика, психоедукація, психологічне консультування, психотерапія.

Mushkevych Myroslava. The effectiveness of psychological support for the development of the indicators of personal functioning of family members with problem children.

Goal. The process of psychological support of families with problem children is aimed at studying the characteristics of the personal functioning of adult members of the family system, their psychological state, the range of problems, tasks to solve them, immersion in real family life.

Methods. Stages of the psychological research involve the initial diagnosis and discussion of the results of standardized and projective methods; study of gaps in the knowledge of family members about the peculiarities of personal functioning at the level of marital and parental subsystems and the provision of specifically necessary information for the development of psychological culture; counseling on improving personal and interpersonal interaction; elaboration of individual and family dysfunctions by psychotherapeutic methods by means of drawing up a diagram, writing a fairy tale, description of a metaphorical family chest.

Results. Content resources of psychological support are focused on prognostic and significant personal predictors of development of personal functioning of adult members of the family system: low level of expression of "hypoprotection"; positive attitude towards the child; low level of expansion of the sphere of parental feelings; cooperation with the child; inversely proportional schizoid type of accentuation; low level of symbiosis with the child; low level of expression "indulgence"; inversely proportional level of minimum sanctions; inversely proportional epileptoid type.

Conclusions. The proposed components of psychological support help to overcome the negative psychological symptoms and increase the functionality of the family system. The symptoms and problems identified at the psychodiagnostic stage are considered as the result of suboptimal, dysfunctional interactions of family members, and not as an attribute of one or another of its members. The foci of psychoeducational, psychoconsultative and psychotherapeutic influence were four non-constructive personal and interpersonal factors, such as "introverted-pedantic personal disposition", "dominant-aggressive personal disposition", "psychasthenic personal disposition", " encourage-educational disposition".

Key words: psychological support, personal characteristics, nuclear family, problem child, psychodiagnostics, psychoeducation, psychological counseling, psychotherapy.

Мушкевич Мирослава. Результативность психологического сопровождения для развития показателей личностного функционирования 


\section{членов семей, имеющих проблемных детей.}

Цель. Процесс психологического сопровождения семей, имеющих проблемных детей, направлен на изучение особенностей личностного функционирования взрослых членов семейной системы, их психологического состояния, круга проблем, задач для их решения, погружение в реальную жизнь семьи.

Методы. Этапность психологического сопровождения подразумевает первичную диагностику и обсуждение результатов стандартизированных и проективных методик; изучение пробелов в знаниях членов семьи об особенностях личностного функционирования на уровне брачной и родительской подсистем и предоставление конкретно необходимой информации развития психологической культуры; консультирование по улучшению личностного и межличностного взаимодействия; проработка индивидуальных и семейных дисфункций психотерапевтическими методами посредством составления диаграммы, написания сказки, описания метафорического семейного сундука.

Результаты. Содержательные ресурсы психологического сопровождения ориентированы на прогностические и значимые личностные предикторы развития личностного функционирования взрослых членов семейной системы: низкий уровень выражения гипопротекции; положительное отношение к ребенку; низкий уровень расширения сферы родительских чувств; кооперация с ребенком; обратно пропорциональный шизоидный тип акцентуации; низкий уровень симбиоза с ребенком; низкий уровень выражения «попустительство»; обратно пропорциональный уровень минимальности санкций; обратно пропорциональный эпилептоидный тип.

Выводы. Предлагаемые составляющие элементы психологического сопровождения способствуют преодолению негативной психологической симптоматики и повышению функциональности семейной системы. Выделенные на психодиагностическом этапе симптомы и проблемы рассмотрены как результат неоптимальных, дисфункциональных взаимодействий членов семьи, а не как атрибут того или иного члена семьи. Фокусами психоэдукациного, психоконсультативного и психотерапевтического воздействия стали выделены четыре неконструктивных личностных и межличностных фактора, таких как «интровертированно-педантическая личностная диспозиция», «доминантно-агрессивная личностная диспозиция», «психастеническая личностная диспозиция», «потуральной воспитания».

Ключевые слова: психологическое сопровождение, личностные характеристики, ядерная семья, проблемный ребенок, психодиагностика, психоэдукация, психологическое консультирование, психотерапия.

Вступ. Основні теоретичні підходи до психологічного супроводу сімей, що мають проблемних дітей, базуються на методологічних та теоретичних засадах системного підходу й описані в структурній 
сімейній психотерапії С. Мінухіна; стратегічному підході Д. Хейлі; гуманістичній сімейній психотерапії К. Вітакера, К. Роджерса, В. Сатір, системному підході до сімейної психотерапії М. Боуена (Минухин, Фишман, 2012; Хейли, 1998; Whitaker, 1982; Роджерс, 2003; Satir, Bitter, 2000; Боуэн, 2005). В основі системного підходу теза про те, що сім'я - єдиний організм, система, що функціонує за своїми законами. Це положення грунтується на холістичному принципі, згідно з яким ціле - це більше ніж проста сума частин. Тобто порушення емоційної сфери дитини, поява іiі поведінкових симптомів не можуть бути пояснені лише особливостями дитячої психіки. Вони безпосередньо пов'язані 3 особливостями внутрісімейної взаємодії, які стають контекстом появи цього виду порушень.

Аналіз досліджень із цісї проблеми. Один зі шляхів психологічної допомоги сім'ям, що мають проблемних дітей, - це психологічний супровід. Суттєвим доробком щодо його технології стали праці І. Баєва, Г. Бардієр, М. Бітянова, О. Казакова, В. Кобильченко, О. Козирева, М. Савчин, Л. Слободенюк, Ю. Слюсарів та ін. (Баева, 2002; Бардиер, 2002; Битянова, 2000; Казакова, 2007; Кобильченко, п.d.; Козырева, 2001; Савчин, 2012; Слободянюк, Холодова, Олексенко, 1996; Слюсарев, 1992). Аналіз публікацій учених засвідчує зосередженість на традиції допомоги сім'ям, що мають проблемних дітей, насамперед на самій дитині, а члени сім'ї залишаються лише ресурсом, умовою чи ж перепоною іiі розвитку. Зважаючи на надбання сучасної психологічної науки, що $є$ теоретичним підгрунтям для подальших роздумів із вивчення питань психологічного супроводу сім'ї, узагальнення потребують іiі недостатньо розроблені аспекти. Так, у наукових працях не виокремлено структурно-функційних характеристик членів сімей, що мають проблемних дітей; дослідження обмежене констатацією необхідності розробки спеціальних заходів, спрямованих на реабілітацію цієї категорії сімей; у межах корекції запропоновано консультування членів сімей спеціалістами різних профілів (психологами, педагогами, лікарями).

У сучасних наукових розвідках з означеної проблеми майже не розглянуто особливості особистісного та сімейного функціонування на рівні шлюбної (чоловік і дружина) та батьківської (батько й мати) підсистем і недостатньо уваги приділено практиці психологічної 
допомоги членам сімей, що мають проблемних дітей. На подальші дослідження заслуговує потреба визначення особливостей особистісної та міжособистісної сфер членів сімей i виявлення взаємозв'язку цих особливостей зі ставленням до дітей. Залишається дискусійним питання про ресурси сім’ї як системи, які забезпечують iii структурно-функційну стабільність; недостатньо описано чинники, що дають змогу членам сімей не лише витримувати стресовий вплив, а й ефективно його вирішувати. Окрім того, не отримали достатнього наукового обгрунтування напрями, зміст i організаційні форми психологічного супроводу сімей, що мають проблемних дітей.

У зв'язку з цим задля успішного та повноцінного функціонування сімей 3 проблемними дітьми пріоритетне завдання психологічної допомоги - це розробка практико-орієнтованої технології супроводу, що актуалізує необхідність визначення особливостей особистісноемоційної й міжособистісної сфер членів сімей, що мають проблемних дітей, і пошуку потенційних ресурсів сімейної системи. Соціальна значущість проблеми, iï недостатня теоретична та експериментальна розробка зумовили вибір теми дослідження.

Мета та завдання дослідження. Для зняття симптоматичних проявів і нормалізації емоційного стану проблемної дитини, а в нашому дослідженні - дошкільника та молодшого школяра, важливо розпочинати роботу з усією сім'єю як системою, передусім із дорослими їі членами на рівні шлюбної та батьківської підсистем.

Методи та процедура дослідження. Щодо оцінки програми комплексного психологічного супроводу сімей, що мають проблемних дітей, як і в процесі первинної психодіагностики, використовувалися стандартизовані опитувальники для вивчення акцентуацій характеру А. Егідеса (у модифікації І. Слободянюка, О. Холодової, О. Олексенко), для вивчення батьківського ставлення А. Варги, В. Століна, для аналізу сімейних взаємин Е. Ейдеміллера, В. Юстицкіса, Фрайбургський особистісний опитувальник (FPI); проєктивні методики: «Автопортрет» О. Кандаурова, «Неіснуюча тварина» М. Друкаревича, «Малюнок сім’ї» Р. Бернса, С. Кауфмана, «Людина під дощем» О. Романової, О. Потьомкіної, «Дім. Дерево. Людина» Д. Бука. Відповідно до результатів первинної психодіагностики було визначено особистісні характеристики членів сімей за критеріями «рівень розвитку показників особистісного функціонування» i «рівень розвитку показників сімейного 
функціонування» в межах кожної дослідницької групи (експериментальної та контрольної) та виокремлено по чотири кластери досліджуваних із різним психотипічним профілем: i3 низьким рівнем інтровертовано-педантичної особистісної диспозиції (12 осіб), із високим рівнем психостенічної особистісної диспозиції (12 осіб), із високим рівнем потуральної виховної диспозиції (12 осіб), із високим рівнем домінантно-агресивної особистісної диспозиції (12 осіб). Потребу в цьому визначало насамперед те, що зміст, форма та характер формувальних заходів у межах реалізації технології психологічного супроводу членів сімей, що мають проблемних дітей, щодо кожного їх типу (психотипічного профілю) мають різну якісну специфіку та модальність, що забезпечує ширші можливості й умови для диференційованої та повної, тому й ефективної реалізації усіх заходів програми психологічного супроводу сімей, що мають проблемних дітей.

Незалежна змінна експерименту - програма психологічного супроводу сімей із проблемними дітьми. Залежна змінна експерименту - результативність подолання неконструктивних особистісних настанов членів сімей, що мають проблемних дітей, ступінь конструктивного розвитку властивостей їх особистісної структури, а також формування якісної структури їх особистісного функціонування.

В експериментальній групі система формувальних заходів мала чітко структурований і організований характер і була побудована на психологічних принципах. Останні забезпечено за допомогою спеціальних форм і методів програми психологічного супроводу, розробленої автором. Формувальні заходи щодо досліджуваних, які ввійшли до контрольної групи, відбувалися на основі стандартного підходу, типового технологічного сценарію психологічної допомоги без використання системи спеціальних психотехнологічних прийомів і методів.

У межах верифікації першого критерію оцінки ефективності програми психологічного супроводу застосовано непараметричний статистичний критерій відмінностей Вілкоксона (Wilcoxon Signed Ranks Test). Із його допомогою було визначено статистично достовірні відмінності в рівні вираження емпіричних показників у досліджуваних із різним психотипічним профілем (типом) до і після реалізації типового технологічного сценарію психологічної допомоги, 
а також в умовах упровадження спеціальної програми психологічного супроводу.

Верифікацію за другим критерієм оцінки ефективності програми психологічного супроводу здійснено за допомогою непараметричного статистичного критерію Хi-квадрат Пірсона (Chi-Square Test), а також обчислення показника відношення шансів (Odds Ratio - OR). Перший критерій використано для порівняння двох емпіричних розподілів якісних ознак, отриманих на двох незалежних вибірках експериментальній i контрольній. Другий статистичний показник забезпечив визначення пропорції частотного відношення якісної ознаки в експериментальній і контрольній вибірках.

Перший етап психологічного супроводу - психодіагностика - дає змогу виокремити основні прогалини в знаннях i навичках членів сімей, що мають проблемних дітей щодо їхнього особистісного та міжособистісного функціонування. Другий етап психологічного супроводу, психоедукаційний, спрямований на навчання - пояснення й донесення потрібної для сімейної ситуації інформації про психологічні негаразди особистісного та міжособистісного функціонування і їх наслідки для кожної особистості та сім’ї загалом, помилки виховних впливів і батьківського ставлення, виділені на діагностичному етапі. Навчання спрямоване на усвідомлення, засвоєння та присвоєння навиків ефективної внутрісімейної комунікації; навичкам активного слухання, вираження думок i почуттів від першої особи («Я-повідомлення»). Під час психоедукації надаються відповіді на запитання; члени сімей ознайомлюються 3 необхідною літературою, яка розкриває та пояснює зміст проблем.

Третій етап психологічного супроводу - це психологічне консультування, в якому основним засобом роботи є бесіда, спрямована на вирішення міжособистісних i внутрішньоособистісних негараздів. Одне із суперечливих питань - відповідність сімейного консультування і сімейної психотерапії. Розподіл цих двох сфер - складне завдання. I консультування, i психотерапія використовують одні й ті самі теоретичні знання і набір технічних засобів. I в першому, i в другому випадках допомога клієнту грунтується на взаємодії між консультантом і клієнтом. Тож сімейне консультування розглянуто як один із різновидів сімейної психотерапії. У нашому дослідженні застосовано індивідуальне та групове консультування. Індивідуальне психологічне консультування 
спрямоване на роботу з одним із членів сім'ї і грунтується на ідеї М. Боуена про те, що зміни навіть одного члена сім’ї змінюють усю систему внутрісімейних стосунків (Боуэн, 2005).

Важливий компонент психологічного супроводу - четвертий етап - психотерапевтичний. Цей вид психологічної роботи з сім'єю особливо важливий тоді, коли в сім'ї простежуємо симптом психологічного неблагополуччя дитини дошкільного та раннього шкільного віку. Головне завдання психотерапевтичного етапу використати техніки сімейної психотерапії та під кутом зору системної сімейної психотерапії пропрацювати кризові процеси сім’і на рівні шлюбної та батьківської підсистем, результатом функціонування яких є емоційно-поведінкові проблеми дитини.

Відповідно до виділених у теоретичному розділі ефективних підходів у роботі із сімейною системою та опираючись на результати емпіричного дослідження, використано психотерапевтичні техніки, які зарекомендували себе досить ефективно в практичній роботі. 1. Діаграма сім’і - вивчення системи внутрісімейних взаємин. 2. «Сімейна скриня» - ще одна ефективна техніка в психотерапії сімейної системи. 3. Психотерапевтична техніка «Написання казки»один із методів психологічної роботи, який використовує казкову форму для інтеграції особистості, розвитку іiі творчих здібностей, розширення свідомості, вдосконалення взаємодії зі світом.

Обговорення результатів. Наступний етап дослідження передбачав експериментальну апробацію й оцінку ефективності програми психологічного супроводу сімей, що мають проблемних дітей, спрямовану на надання психологічної допомоги самим членам сімей, що мають проблемних дітей, на подолання неконструктивних настанов їхнього особистісного функціонування, а також на розвиток функційності сімейної системи.

Перейдемо до оцінки ефективності програми психологічного супроводу сімей, що мають проблемних дітей, за критерієм «рівень розвитку показників особистісного функціонування». Під час аналізу змін у рівні вираження емпіричних показників досліджуваних різного психотипічного профілю виявлено різницю в результатах двох діагностичних зрізів в експериментальній і контрольній вибірках. Проаналізуємо послідовно результати порівняння вираження емпіричних показників у досліджуваних обох груп до i після застосування традиційної програми психологічної допомоги, а також 
в умовах упровадження спеціальної програми ПС (див. табл. 1).

Порівняння результатів першого та другого діагностичних зрізів у контрольній і експериментальній групах щодо відмінностей між рівнем вираження психотипічних властивостей у досліджуваних iз низьким рівнем інтровертовано-педантичної особистісної диспозиції дало змогу підтвердити їх достовірність (див. табл. 1).

Таблиияя 1

Емпіричні показники досліджуваних контрольної й експериментальної груп 3 низьким рівнем інтровертованопедантичної особистісної диспозиції

\begin{tabular}{|c|c|c|c|c|c|c|c|c|c|c|}
\hline \multirow{3}{*}{$\begin{array}{l}\text { Емпіричні } \\
\text { показники }\end{array}$} & \multicolumn{5}{|c|}{ Контрольна група } & \multicolumn{5}{|c|}{ Експериментальна група } \\
\hline & \multicolumn{2}{|c|}{$\begin{array}{l}\text { результати } \\
\text { I зрізу }\end{array}$} & \multicolumn{2}{|c|}{$\begin{array}{l}\text { Результати } \\
\text { II зрізу }\end{array}$} & \multirow{2}{*}{$\mathrm{P}$} & \multicolumn{2}{|c|}{$\begin{array}{l}\text { результати } \\
\text { I зрізу }\end{array}$} & \multicolumn{2}{|c|}{$\begin{array}{l}\text { результати } \\
\text { II зрізу }\end{array}$} & \multirow{2}{*}{$P$} \\
\hline & $\mathrm{M}_{\mathrm{x}}$ & $\sigma_{\mathrm{x}}$ & $\mathrm{M}_{\mathrm{x}}$ & $\sigma_{\mathrm{x}}$ & & $\mathrm{M}_{\mathrm{x}}$ & $\sigma_{\mathrm{x}}$ & $\mathrm{M}_{\mathrm{x}}$ & $\sigma_{\mathrm{x}}$ & \\
\hline Шизоїдний тип & 4,2 & 1,9 & 4,3 & 2,0 & 0,738 & 4,2 & 2,0 & 7,8 & 1,9 & 0,000 \\
\hline Астенічний тип & 3,7 & 1,6 & 3,8 & 1,7 & 0,692 & 3,6 & 1,7 & 6,9 & 1,5 & 0,000 \\
\hline Епілептоїдний тип & 4,3 & 2,1 & 4,5 & 1,9 & 0,574 & 4,4 & 2,2 & 6,3 & 2,0 & 0,007 \\
\hline
\end{tabular}

Як підтверджують дані 3 табл. 1, у досліджуваних експериментальної групи 3 низьким рівнем інтровертованопедантичної особистісної диспозиції після впровадження спеціальної програми психологічного супроводу простежено виражену позитивну динаміку за всіма емпіричними показниками, що змістовно визначають структуру їхнього психотипічного профілю. Результати вимірювання їх емпіричних показників у межах другого діагностичного зрізу за рівнем вираження виявилися достовірно вищими, ніж за результатами першого діагностичного зрізу.

Так, достовірний характер змін із високим рівнем статистичної значущості зафіксовано щодо таких емпіричних показників: шизоїдний тип $(\mathrm{p}<0,001)$, астенічний тип $(\mathrm{p}<0,001)$, епілептоїдний тип $(\mathrm{p}<0,01)$. Це дає підстави здійснити грунтовний аналіз та інтерпретацію виявлених закономірностей.

3 огляду на достовірний характер приросту значень усіх показників досліджуваних із низьким рівнем інтровертованопедантичної особистісної диспозиції, можемо стверджувати, що 
спеціальна програма психологічного супроводу стала важливим чинником якісної трансформації змістовно-структурних елементів їхнього психотипу в напрямі розвитку властивостей здорового консервативного педантизму на основі особистісної інтровертованої орієнтації.

Ба більше, дані таблиці дають змогу констатувати, що на відміну від експериментальної, в контрольній групі досліджуваних із низьким рівнем інтровертовано-педантичної особистісної диспозиції за результатами другого діагностичного зрізу, хоча й відбулися певні зміни в рівні вираження емпіричних показників, що змістовно визначають структуру їхнього психотипічного профілю, проте не сягнули порога статистичної значимості (р>0,05).

Так, порівняння середніх значень вираження емпіричних показників досліджуваних за результатами двох діагностичних зрізів засвідчує тенденцію до їх підвищення, що також може бути підставою й аргументом для прийняття рішення щодо ефективності формувальних заходів у межах традиційної програми психологічної допомоги. Єдиним стримувальним чинником, що знижує наукову цінність такого рішення, є високий ризик його випадковості.

Тобто порівняльний аналіз результативності формувальних заходів у межах традиційної програми психологічної допомоги, а також в умовах упровадження спеціальної програми психологічного супроводу досліджуваних iз низьким рівнем інтровертованопедантичної особистісної диспозиції, дає змогу зробити висновок про їх високу ефективність щодо експериментальної групи.

Порівняння результатів першого та другого діагностичних зрізів у контрольній і експериментальній групах щодо відмінностей між рівнем вираження психотипічних властивостей у досліджуваних iз високим рівнем домінантно-агресивної особистісної диспозиції також дало змогу виявити важливі закономірності (див. табл. 2).

Як засвідчують дані таблиці, в досліджуваних експериментальної групи 3 високим рівнем домінантно-агресивної особистісної диспозиції після впровадження спеціальної програми психологічного супроводу простежено виражену динаміку за всіма емпіричними показниками, що змістовно визначають структуру їхнього психотипічного профілю. Результати вимірювання емпіричних показників у межах другого діагностичного зрізу за рівнем вираження достовірно нижчі, ніж за результатами першого 
діагностичного зрізу.

Таблиия 2

Емпіричні показники досліджуваних контрольної й експериментальної груп із високим рівнем домінантноагресивної особистісної диспозиції

\begin{tabular}{|c|c|c|c|c|c|c|c|c|c|c|}
\hline \multirow{3}{*}{$\begin{array}{l}\text { Емпіричні } \\
\text { показники }\end{array}$} & \multicolumn{5}{|c|}{ Контрольна група } & \multicolumn{5}{|c|}{ Експериментальна група } \\
\hline & \multicolumn{2}{|c|}{$\begin{array}{l}\text { результати } \\
\text { I зрізу }\end{array}$} & \multicolumn{2}{|c|}{$\begin{array}{l}\text { результати } \\
\text { II зрізу }\end{array}$} & \multirow{2}{*}{$\mathrm{P}$} & \multicolumn{2}{|c|}{$\begin{array}{l}\text { результати } \\
\text { I зрізу }\end{array}$} & \multicolumn{2}{|c|}{$\begin{array}{l}\text { результати } \\
\text { II зрізу }\end{array}$} & \multirow{2}{*}{$P$} \\
\hline & $\mathrm{M}_{\mathrm{x}}$ & $\sigma_{\mathrm{x}}$ & $\mathrm{M}_{\mathrm{x}}$ & $\sigma_{\mathrm{x}}$ & & $\mathrm{M}_{\mathrm{x}}$ & $\sigma_{\mathrm{x}}$ & $\mathrm{M}_{\mathrm{x}}$ & $\sigma_{\mathrm{x}}$ & \\
\hline $\begin{array}{l}\text { Реактивна } \\
\text { агресивність }\end{array}$ & 7,6 & 1,6 & 6,0 & 1,3 & 0,029 & 7,7 & 1,6 & 4,8 & 1,4 & 0,000 \\
\hline $\begin{array}{l}\text { Маскулінність } \\
\text { фемінність }\end{array}$ & 7,3 & 2,1 & 7,2 & 1,8 & 0,736 & 7,3 & 2,1 & 5,8 & 1,8 & 0,037 \\
\hline $\begin{array}{l}\text { Спонтанна } \\
\text { агресивність }\end{array}$ & 7,0 & 1,5 & 5,3 & 1,4 & 0,018 & 6,9 & 1,4 & 4,2 & 1,1 & 0,000 \\
\hline
\end{tabular}

Так, достовірний характер змін із високим рівнем статистичної значущості зафіксовано щодо таких емпіричних показників: реактивна агресивність $(\mathrm{p}<0,001)$, спонтанна агресивність $(\mathrm{p}<0,001)$, маскулінність/фемінність $(\mathrm{p}<0,05)$. Тож перейдемо до грунтовного аналізу й інтерпретації виявлених закономірностей.

Якщо змістовими елементами особистісно-поведінкової структури досліджуваних цього типу на першому етапі діагностики були реактивна та спонтанна агресивність, то вже за підсумками повторної діагностики їх «питома» вага суттєво зменшилась, а агресивність до соціального оточення трансформувалася в напрямок до прагнення здорового домінування. Крім цього, цей психотип став збалансованішим за параметром «маскулінність/фемінність», оскільки основні атрибути вираженого «чоловічого» поведінкового патерну досліджуваних втратили всі ознаки гіпертрофованості.

Дані таблиці також дають змогу констатувати, що в контрольній групі досліджуваних із високим рівнем домінантно-агресивної особистісної диспозиції за результатами другого діагностичного зрізу теж відбулися певні зміни в рівні вираження емпіричних показників, що змістовно визначають структуру їхнього психотипічного профілю.

Порівняння середніх значень вираження емпіричних даних виявляє достовірність їх динаміки щодо реактивної $(\mathrm{p}<0,05)$ та спонтанної агресивності $(\mathrm{p}<0,05)$. Стосовно показника 
«маскулінність/фемінність», то, згідно 3 результатами повторної діагностики, зміна рівня його вираження не продемонструвала статистично значимого характеру $(\mathrm{p}>0,05)$.

Тобто порівняльний аналіз результативності формувальних заходів у межах традиційної програми психологічної допомоги, а також в умовах упровадження спеціальної програми психологічного супроводу досліджуваних із високим рівнем домінантно-агресивної особистісної диспозиції дає підставу зробити висновок про їх високу ефективність щодо досліджуваних експериментальної групи.

Порівняння результатів першого та другого діагностичних зрізів у контрольній і експериментальній групах щодо відмінностей між рівнем вираження психотипічних властивостей у досліджуваних із високим рівнем психостенічної особистісної диспозиції підтвердило їх достовірний характер (див. табл. 3).

Таблицуя 3

Емпіричні показники досліджуваних контрольної й експериментальної груп із високим рівнем психостенічної особистісної диспозиції

\begin{tabular}{|c|c|c|c|c|c|c|c|c|c|c|}
\hline \multirow{3}{*}{$\begin{array}{l}\text { Емпіричні } \\
\text { показники }\end{array}$} & \multicolumn{5}{|c|}{ Контрольна група } & \multicolumn{5}{|c|}{ Експериментальна група } \\
\hline & \multicolumn{2}{|c|}{$\begin{array}{c}\text { результати } \\
\text { I зрізу }\end{array}$} & \multicolumn{2}{|c|}{$\begin{array}{c}\text { результати } \\
\text { II зрізу }\end{array}$} & \multirow{2}{*}{$\mathrm{P}$} & \multicolumn{2}{|c|}{$\begin{array}{l}\text { результати } \\
\text { I зрізу }\end{array}$} & \multicolumn{2}{|c|}{$\begin{array}{l}\text { результати } \\
\text { II зрізу }\end{array}$} & \multirow{2}{*}{$\mathrm{P}$} \\
\hline & $\mathrm{M}_{\mathrm{x}}$ & $\sigma_{\mathrm{x}}$ & $\mathrm{M}_{\mathrm{x}}$ & $\sigma_{\mathrm{x}}$ & & $\mathrm{M}_{\mathrm{x}}$ & $\sigma_{\mathrm{x}}$ & $\mathrm{M}_{\mathrm{x}}$ & $\sigma_{\mathrm{x}}$ & \\
\hline Сенситивний тип & 8,9 & 2,2 & 8,6 & 2,0 & 0,527 & 8,9 & 2,2 & 6,7 & 1,9 & 0,006 \\
\hline Лабільний тип & 10,0 & 2,0 & 9,8 & 1,7 & 0,673 & 10,1 & 2,0 & 6,3 & 1,8 & 0,000 \\
\hline Циклоїдний тип & 9,7 & 2,5 & 9,5 & 2,2 & 0,602 & 9,7 & 2,6 & 5,1 & 2,0 & 0,000 \\
\hline Гіпотимічний тип & 7,3 & 2,0 & 7,1 & 1,8 & 0,544 & 7,4 & 2,1 & 5,0 & 1,8 & 0,010 \\
\hline Психостеноїдний тип & 11,0 & 2,4 & 10,9 & 2,5 & 0,769 & 10,9 & 2,3 & 5,4 & 1,9 & 0,000 \\
\hline
\end{tabular}

Як підтверджує табл. 3, в представників експериментальної групи з високим рівнем психостенічної особистісної диспозиції після впровадження спеціальної програми психологічного супроводу спостерігається виражена динаміка за всіма емпіричними показниками, що змістовно визначають структуру їхнього психотипічного профілю. Результати вимірювання їх емпіричних 
показників у межах другого діагностичного зрізу за рівнем вираження виявилися достовірно нижчими, ніж за результатами першого діагностичного зрізу.

Так, достовірний характер змін із високим рівнем статистичної значущості зафіксовано щодо таких емпіричних показників: психостеноїдний тип $(p<0,001)$, циклоїдний тип $(p<0,001)$, лабільний тип ( $<<0,001)$, сенситивний тип $(p<0,01)$, гіпотимічний тип $(p<0,01)$. Проінтерпретуємо ці результати.

Очевидно, що домінування тривожних тенденцій 3 проявом постійної невпевненості в собі, нерішучості, боязливості й уразливості (як змістових елементів якісної структури особистісного функціонування досліджуваних цього типу) під впливом формувальних заходів трансформовалося у симптомокомплекс конструктивних особистісних настанов, передусім пов'язаних зі спроможністю до здорового самоконтролю, самостійності, впевненості та рішучості (як на етапі прийняття рішень, так і під час їх реалізації). Цей характер динамічної трансформації зафіксовано щодо таких ознак «незрілої», інфантильної особистості як замкнутість, схильність до самоприниження, розгубленість у важких ситуаціях, підвищена образливість і конфліктність на грунті завданих образ. Отож, сформований під час психологічного супроводу досліджуваних цього типу симптомокомлекс психологічних новоутворень забезпечив основу для розвитку конструктивних патернів їх особистісного функціонування.

Також дані таблиці дають змогу констатувати, що на відміну від експериментальної, у контрольній групі досліджуваних із високим рівнем психостенічної особистісної диспозиції за результатами другого діагностичного зрізу хоча й відбулися певні зміни в рівні вираження емпіричних показників, що змістовно визначають структуру їхнього психотипічного профілю, проте не досягнули порога статистичної значимості ( $>>0,05)$.

Тобто порівняльний аналіз результативності формувальних заходів у межах традиційної програми психологічної допомоги, а також в умовах упровадження спеціальної програми психологічного супроводу досліджуваних із високим рівнем психостенічної особистісної диспозиції, дає підставу зробити висновок про їх високу ефективність щодо експериментальної групи.

Порівняння результатів першого та другого діагностичних зрізів 
у контрольній і експериментальній групах щодо відмінностей між рівнем вираження психотипічних властивостей у досліджуваних із високим рівнем потуральної виховної диспозиції підтвердило їх достовірність (див. табл. 4).

Таблиця 4

Емпіричні показники досліджуваних контрольної й експериментальної груп із високим рівнем потуральної виховної диспозиції

\begin{tabular}{|c|c|c|c|c|c|c|c|c|c|c|}
\hline \multirow{3}{*}{$\begin{array}{l}\text { Емпіричні } \\
\text { показники }\end{array}$} & \multicolumn{5}{|c|}{ Контрольна група } & \multicolumn{5}{|c|}{ Експериментальна група } \\
\hline & \multicolumn{2}{|c|}{$\begin{array}{l}\text { результати } \\
\text { I зрізу }\end{array}$} & \multicolumn{2}{|c|}{$\begin{array}{l}\text { результати } \\
\text { II зрізу }\end{array}$} & \multirow{2}{*}{$\mathrm{P}$} & \multicolumn{2}{|c|}{$\begin{array}{l}\text { результати } \\
\text { I зрізу }\end{array}$} & \multicolumn{2}{|c|}{$\begin{array}{l}\text { результати } \\
\text { II зрізу }\end{array}$} & \multirow{2}{*}{$\mathrm{P}$} \\
\hline & $\mathrm{M}_{\mathrm{x}}$ & $\sigma_{\mathrm{x}}$ & $\mathrm{M}_{\mathrm{x}}$ & $\sigma_{\mathrm{x}}$ & & $\mathrm{M}_{\mathrm{x}}$ & $\sigma_{\mathrm{x}}$ & $\mathrm{M}_{\mathrm{x}}$ & $\sigma_{\mathrm{x}}$ & \\
\hline $\begin{array}{l}\text { Розширення сфери } \\
\text { батьківських почуттів }\end{array}$ & 3,1 & 1,2 & 3,0 & 1,1 & 0,676 & 3,1 & 1,3 & 2,1 & 1,1 & 0,008 \\
\hline Потурання & 4,6 & 1,5 & 4,4 & 1,3 & 0,524 & 4,7 & 1,5 & 2,4 & 1,2 & 0,000 \\
\hline Мінімальність санкцій & 3,0 & 1,1 & 2,9 & 1,1 & 0,619 & 3,0 & 1,1 & 2,1 & 0,9 & 0,009 \\
\hline
\end{tabular}

Як засвідчують дані 3 табл. 4, в досліджуваних експериментальної групи 3 високим рівнем потуральної виховної диспозиції після впровадження спеціальної програми психологічного супроводу простежуємо виражену позитивну динаміку за всіма емпіричними показниками, що змістовно визначають структуру їхнього психотипічного профілю. Результати вимірювання їхніх емпіричних даних у межах другого діагностичного зрізу за рівнем вираження виявилися достовірно нижчими, ніж за результатами першого діагностичного зрізу.

Так, достовірний характер змін із високим рівнем статистичної значущості зафіксовано щодо таких емпіричних показників як потурання $(\mathrm{p}<0,001)$, розширення сфери батьківських почуттів $(p<0,01)$, мінімальність санкцій $(p<0,01)$. Отож, перейдемо до грунтовного аналізу й інтерпретації виявлених закономірностей.

Зважаючи на отримані результати, можемо стверджувати, що формувальний вплив щодо досліджуваних цього типу мав очевидний результативний характер, оскільки сприяв конструктивній трансформації стратегії потуральної протекції у сфері виховання дитини, ефективній корекції їхньої неконструктивної особистісної 
позицї, пов'язаної 3 вихованням у дитини некритичної вседозволеності та доступності об’єкта бажань і потреб.

Якщо проаналізувати дані, представлені в таблиці, то стає очевидним, що в контрольній групі досліджуваних із високим рівнем потуральної виховної диспозиції під час застосування традиційної програми психологічної допомоги хоча й відбулися певні зміни в рівні вираження емпіричних показників, що змістовно визначають структуру їхнього психотипічного профілю, проте не досягнули порога статистичної значимості (p>0,05).

Висновки й перспективи. Отже, порівняльний аналіз результативності формувальних заходів щодо досліджуваних із високим рівнем потуральної виховної диспозиції в межах застосування традиційної технології психологічної допомоги, а також в умовах упровадження спеціальної програми психологічного супроводу дає підставу зробити висновок про їх високу ефективність щодо експериментальної групи.

Узагальнюючи результати порівняльного аналізу результативності формувальних заходів у досліджуваних експериментальної та контрольної груп за критерієм «рівень розвитку показників особистісного функціонування», можемо констатувати, що, порівняно з традиційною програмою психологічної допомоги, запровадження спеціальної програми психологічного супроводу забезпечило ефективнішу корекцію неконструктивних особистісних настанов членів сімей, що мають проблемних дітей, а також достовірно вищий ступінь розвитку тих властивостей їхньої особистісної структури, які покладено в основі конструктивних патернів особистісного функціонування.

Перспективними напрямами наукової роботи є вдосконалення програми психологічного супроводу сімей, що мають проблемних дітей, поглиблення знань про структурно-функціональні особливості iі складників.

\section{Література}

1. Баева, И. А. (2002). Психологическая безопасность в образовании. Санкт-Петербург: Союз.

2. Бардиер, Г.Л. (2002). Почему психолог похож на кота: тонкости психологической помощзи детям. Москва: Генезис.

3. Битянова, М. Р. (2000). Организация психологической работы в школе. Москва: Генезис. 
4. Бернс, Р. С., Кауфман, С. Х. (2000). Кинетический рисунок семьи. Москва: Смысл.

5. Боуэн, М. (2005). Теория семейных систем Мюррея Боуэна: основные понятия, методы и клиническая практика. Москва: Когито-центр.

6. Казакова, Е. И. (2007). Толерантность - путь к развитию. СанктПетербург: Ютас.

7. Кобильченко В. Супровід як проблема сучасної психологічної науки. URL : http://ispukr.org.ua/kobulchenko_v.html

8. Козырева, Е. А. (2001). Теоретико-технологические аспекты психологопедагогического сопровождения детей, их учителей и родителей. Школьный психолог, 33, 7-15.

9. Минухин, С., Фишман, Ч. (2012). Техники семейной терапии. Пер. с англ. А. Д. Иорданского. Москва: Класс.

10. Роджерс, К. Ю. (2003). Клиентцентрированный/ человекоцентрированный подход в психотерапии. Личностноориентированное консультирование в образовании. Москва: ПЕР СЭ.

11. Савчин, М. В. (2012). Психологічний супровід розвитку особистості студента 3 обмеженими можливостями. Вісник Національної академії Державної прикордонної служби України, 1. URL: http://nbuv.gov.ua/UJRN/Vnadps_2012_1_41

12. Слободянюк, І. А., Холодова, О. О., Олексенко, О. І. (1996). Психологопедагогічна допомога дітям з акиентуачіями характеру. Вінниця.

13. Слюсарев, Ю. В. (1992). Психологическое сопровождение как фактор активизации саморазвития личности. Автореф. дис. на соискание ученой степени канд. психол. наук: 19.00.01. Санкт-Петербург. гос. ун-т. СанктПетербург.

14. Хейли, Дж. (1998). Терапия испытанием: необычные способы менять поведение. Москва: Класс.

15. Satir, V., Bitter, J. (2000). The therapist andasi family theraphy: Satir's human validation process model. Family counseling and theraphy, 62-101.

16. Whitaker, C. A. (1982). From psyche to system: the evolving therapy of Carl Whitaker. New York: Guilford Press, 365-375.

\section{References}

1. Baeva, I. A. (2002). Psihologicheskaya bezopasnost $v$ obrazovanii [Psychological security in education]. Sankt-Peterburg: Soyuz [in Russian].

2. Bardier, G. L. (2002). Pochemu psiholog pohozh na kota: tonkosti psihologicheskoy pomoschi detyam [Why a psychologist is like a cat: the subtleties of psychological assistance to children]. Moskva: Genezis [in Russian].

3. Bityanova, M. R. (2000). Organizatsiya psihologicheskoy rabotyi $v$ shkole [Organization of psychological work at school]. Moskva: Genezis [in Russian].

4. Berns, R. S., Kaufman, S. X. (2000). Kineticheskiy risunok semi [Kinetic drawing of the family]. Moskva: Smyisl [in Russian].

5. Bouen, M. (2005). Teoriya semeynyih sistem Myurreya Bouena: osnovnyie 
ponyatiya, metodyi i klinicheskaya praktika [Murray Bowen's theory of family systems: basic concepts, methods and clinical practice]. Moskva: Kogito-tsentr [in Russian].

6. Kazakova, E. I. (2007). Tolerantnost - put $k$ razvitiyu [Tolerance is the path to development]. Sankt-Peterburg: Yutas [in Russian].

7. Kobylchenko, V. (n.d.). Suprovid yak problema suchasnoi psykholohichnoi nauky [Support as a problem of modern psychological science]. URL: http://ispukr.org.ua/kobulchenko_v.html [in Ukrainian].

8. Kozyireva, E. A. (2001). Teoretiko-tehnologicheskie aspektyi psihologopedagogicheskogo soprovozhdeniya detey, ih uchiteley i roditeley [Theoretical and technological aspects of psychological and pedagogical support of children, their teachers and parents]. Shkolnyiy psiholog - School psychologist, 33, 7-15 [in Russian].

9. Minuhin, S., Fishman, Ch. (2012). Tehniki semeynoy terapii [Family therapy techniques]. Moskva: Klass [in Russian].

10. Rodzhers, K. Yu. (2003). Klienttsentrirovannyiy / chelovekotsentrirovannyiy podhod v psihoterapii [Client-centered / person-centered approach in psychotherapy]. Lichnostno-orientirovannoe konsultirovanie $v$ obrazovanii - Person-centered educational counseling. Moskva: PER SE [in Russian].

11. Savchyn, M. V. (2012). Psykholohichnyi suprovid rozvytku osobystosti studenta z obmezhenymy mozhlyvostiamy [Psychological support of personality development of a student with disabilities]. Visnyk Natsionalnoi akademii Derzhavnoi prykordonnoi sluzhby Ukrainy - Bulletin of the National Academy of the State Border Guard Service of Ukraine, 1. URL: http://nbuv.gov.ua/UJRN/Vnadps_2012_1_41 [in Ukrainian].

12. Slobodianiuk, I. A., Kholodova, O. O., Oleksenko, O. . (1996). Psykholohopedahohichna dopomoha ditiam z aktsentuatsiiamy kharakteru [Psychological and pedagogical assistance to children with character accentuations]. Vinnytsia [in Ukrainian].

13. Slyusarev, Yu. V. (1992). Psihologicheskoe soprovozhdenie kak faktor aktivizatsii samorazvitiya lichnosti [Psychological support as a factor in the activation of personality self-development]. Extended abstract of candidate's thesis. Sankt-Peterburg. gos. un-t. Sankt-Peterburg [in Russian].

14. Hayley, J. (1998). Challenge therapy: unusual ways to change behavior [Challenge therapy: unusual ways to change behavior]. Moscow: Class [in Russian].

15. Satir, V., Bitter, J. (2000). The therapist andasi family theraphy: Satir's human validation process model. Family counseling and theraphy, 62-101.

16. Whitaker, C. A. (1982). From psyche to system: the evolving therapy of Carl Whitaker. New York: Guilford Press, 365-375.

Received: 11.10.2021

Accepted: 09.11.2021 